\title{
A Review of ENSO Influence on the North Atlantic. A Non-Stationary Signal
}

\author{
Belén Rodríguez-Fonseca ${ }^{1,2, *}$, Roberto Suárez-Moreno ${ }^{1,2}$, Blanca Ayarzagüena ${ }^{3}$, \\ Jorge López-Parages ${ }^{4}$, Iñigo Gómara ${ }^{1,2}$, Julián Villamayor ${ }^{1,2}$, Elsa Mohino ${ }^{1}$, \\ Teresa Losada ${ }^{1,2}$ and Antonio Castaño-Tierno ${ }^{1,2}$ \\ 1 Departamento Geofísica y Meteorología, Universidad Complutense de Madrid, Madrid 28040, Spain; \\ roberto.suarez@fis.ucm.es (R.S.-M.); i.gomara@ucm.es (I.G.); julian.villamayor@fis.ucm.es (J.V.); \\ emohino@fis.ucm.es (E.M.); tldoval@fis.ucm.es (T.L.); acastanotierno@gmail.com (A.C.-T.) \\ 2 Instituto de Geociencias (IGEO), Universidad Complutense de Madrid (UCM), \\ Consejo Superior de Investigaciones Científicas (CSIC), Madrid 28040, Spain \\ 3 College of Engineering, Mathematics and Physical Sciences, University of Exeter, Exeter EX4 4QE, UK; \\ b.ayarzaguena@exeter.ac.uk \\ 4 Dipartimento di Scienze Ambientali, Informatica e Statistica, Università Ca' Foscari di Venezia, Mestre 30172, \\ Italy; jorge.parages@unive.it \\ * Correspondence: brfonsec@ucm.es; Tel.: +34-913-94-45-13
}

Academic Editor: Agus Santoso

Received: 18 February 2016; Accepted: 17 June 2016; Published: 25 June 2016

\begin{abstract}
The atmospheric seasonal cycle of the North Atlantic region is dominated by meridional movements of the circulation systems: from the tropics, where the West African Monsoon and extreme tropical weather events take place, to the extratropics, where the circulation is dominated by seasonal changes in the jetstream and extratropical cyclones. Climate variability over the North Atlantic is controlled by various mechanisms. Atmospheric internal variability plays a crucial role in the mid-latitudes. However, El Niño-Southern Oscillation (ENSO) is still the main source of predictability in this region situated far away from the Pacific. Although the ENSO influence over tropical and extra-tropical areas is related to different physical mechanisms, in both regions this teleconnection seems to be non-stationary in time and modulated by multidecadal changes of the mean flow. Nowadays, long observational records (greater than 100 years) and modeling projects (e.g., CMIP) permit detecting non-stationarities in the influence of ENSO over the Atlantic basin, and further analyzing its potential mechanisms. The present article reviews the ENSO influence over the Atlantic region, paying special attention to the stability of this teleconnection over time and the possible modulators. Evidence is given that the ENSO-Atlantic teleconnection is weak over the North Atlantic. In this regard, the multidecadal ocean variability seems to modulate the presence of teleconnections, which can lead to important impacts of ENSO and to open windows of opportunity for seasonal predictability.
\end{abstract}

Keywords: El Niño-Southern Oscillation; North Atlantic region; teleconnections; Western African Monsoon; hurricanes; stratosphere; Euro-Mediterranean rainfall; North Atlantic Oscillation; Atlantic Multidecadal Oscillation; non-stationarity

\section{Introduction}

El Niño-Southern Oscillation (ENSO) is the leading mode of climate variability at interannual timescales, and the key phenomenon for seasonal climate forecasting worldwide. It corresponds to an air-sea coupled mode, characterized by changes in sea surface temperature (SST) and sea level pressure (SLP) gradients over the tropical Pacific. During an El Niño (La Niña) event, the diabatic heating (cooling) associated with increased (decreased) condensation over the equatorial Pacific alters 
the energy balance in the tropics and therefore the global atmospheric circulation. This alteration triggers the appearance of atmospheric teleconnections in regions far away from the tropical Pacific (e.g., the North Atlantic). The present article is mainly focused on the North Atlantic eastern sector, a region in which the ENSO teleconnection is still poorly understood and controversial. This connection, when established, takes place through different mechanisms that involve the divergent and non-divergent circulation over the troposphere and the stratosphere [1]. In this regard, the atmospheric seasonal cycle of the North Atlantic acts as a modulator of the ENSO teleconnection, whose strength is sensitive to the time of year.

The North Atlantic Oscillation (NAO) dominates climate variability over the extra-tropical North Atlantic. This oscillation is defined as an exchange of mass between subtropical and subpolar regions and is related to changes in the position of the eddy-driven jet-stream ([2], and papers therein). The NAO exhibits different global signatures, being related to a Tropical Northern Hemisphere pattern (TNH) in winter [3] and to a more internal and northward shifted configuration in summer [4]. In winter, the NAO is also highly influenced by the polar stratosphere [5]. The NAO has profound impacts on a variety of ecological processes and, consequently, on species' abundance and dynamics [6]. Although most of the variability associated with the NAO is explained by internal and non-linear processes [7-9], some predictability has been found from ENSO [1] and the tropical North Atlantic.

The importance of tropical versus extratropical ocean-atmosphere interactions on the NAO has not been fully determined yet ([2]; and papers therein). Although traditionally the scientific community has focused on the ENSO influence over the North Pacific and the American Continent [10], several studies have also suggested a consistent and statistically significant impact of ENSO over the North Atlantic and Europe (NAE; [11-16]). The ENSO signature over the NAE is stronger during late winter and early spring, when El Niño (La Niña) is typically accompanied by a weakening (strengthening) of the subtropical high surface pressure system associated with a negative (positive) NAO-like pattern. In winter, ENSO influences the polar stratosphere, by weakening (strengthening) the polar vortex during El Niño (La Niña) conditions [11,17], a result confirmed by model simulations and long reanalysis data records (e.g., $[18,19])$. Although the anomalous circulation associated with ENSO reaches Europe in a stationary way regardless of the period considered [3], recent observation- and model-based studies suggest that the impact on rainfall is not stationary in time and can be modulated by multidecadal changes in the oceanic conditions [20-22]. The time-varying influence of ENSO over Europe could also be due to multidecadal changes in the NAO structure and strength [23-26].

In the Tropical North Atlantic (TNA), the so-called West African Monsoon (WAM) is also affected by ENSO during boreal summer (June to September). The WAM affects mainly the sub-Saharan semi-arid region of Sahel, whose economy and sustainability are particularly vulnerable to fluctuations in the amount of rainfall. This region experiences a strong seasonal rainfall regime between the months of July and September, which is related to a semi-annual shift of the Intertropical Convergence Zone (ITCZ) and the temperature contrast between the Sahara and the Gulf of Guinea. Although General Circulation Model (GCM) experiments show that ENSO produces a decrease (increase) of rainfall under its positive (negative) phase, its impact has been found to be non-stationary in time [27,28], being the relationship stronger in some decades and weaker in others [29].

Also in the tropics, and in relation to the African Easterly Waves (which also modulate rainfall during the WAM), hurricanes have ENSO as the primary source of predictability at interannual scales $[10,30]$. These extraordinary energetic weather systems often produce very strong winds, heavy precipitation, and storm surge events over the tropical areas they affect [31-34]. Nevertheless, the stability in time of ENSO impact on Atlantic hurricane activity has been little analyzed in the literature so far.

Thus, a common feature for European and tropical North Atlantic regions is that ENSO teleconnection seems to be non-stationary in time. In the present paper, we provide further insight into the ENSO impact on the anomalous rainfall over these regions under a non-stationary approach. This article discusses the available literature, trying to conciliate different results that have emerged 
during the last decades mainly for seasonal predictability purposes. For the sake of simplicity, the study is focused on boreal late-winter and spring in the extratropics, and on summer in the tropics.

With this aim, different analyses are performed using observed and reanalysis data (Section 2). A detailed description of the stationarity of the ENSO impact over the tropical/extratropical North Atlantic and its influence in seasonal predictability is provided in Section 3. The article concludes with a discussion and a short summary in Section 4 .

\section{Data and Methodology}

Along this review paper, different analyses are performed to illustrate the non-stationarity of the ENSO teleconnections on North Atlantic climate variability. For this purpose, the following datasets are used:

- The Global Land Precipitation data from the Climatic Research Unit (CRU)—University of East Anglia: The dataset has a horizontal resolution of $0.5^{\circ} \times 0.5^{\circ}$ in longitude/latitude and covers the period 1901-2014 [35].

- The Sea Surface Temperature and sea ice data from the Met Office Hadley Centre (HadISST): These data span from 1870 to the present on a monthly basis and have a horizontal longitude/latitude resolution of $1^{\circ} \times 1^{\circ}[36]$.

- The Atlantic Hurricane Database 2 (HURDAT2): The database goes back to 1851, and provides six-hourly information on the location, maximum winds, central pressure, and (post 2004 only) size of all known tropical and subtropical cyclones in the North Atlantic. As a note of caution, this dataset is far from being complete and accurate for the entire century and a half [37].

- The National Centers for Environmental Prediction (NCEP)/National Center for Atmospheric Research (NCAR) re-analysis [38]: It spans from 1948 to the present and has a horizontal resolution of $2.5^{\circ} \times 2.5^{\circ}$. In the vertical, it extends from the surface up to $3 \mathrm{hPa}$ and it is available every 6-h, and at daily and monthly timescales.

Most of the results are presented in terms of sliding window correlations, regression and correlation maps [39], using at least a 90\% confidence interval when tackling statistical significance. The significance analyses are mainly based on non-parametric Monte-Carlo approaches with a confidence interval of $90 \%$.

Finally, a statistical hindcast based on Maximum Covariance Analysis (MCA) between SST and rainfall is performed using the SST-based Statistical Seasonal foreCAST (S4CAST; [40]), a model developed to determine rainfall predictability over different regions and time periods. The leading mode of co-variability between rainfall and SST is described for different periods, and a hindcast for Sahelian and Euro-Mediterranean rainfall is performed.

\section{Results}

\subsection{ENSO Influence on the Tropical North Atlantic}

\subsubsection{ENSO Impact on the West African Monsoon}

West Africa is the westernmost region of Africa, bordering the eastern coast of the North Atlantic sector. It hosts a monsoon in boreal summer, known as the West African Monsoon (WAM).

The decadal influence of the Pacific on the Sahel is very robust [41]. The influence of ENSO on the variability of WAM at interannual timescales has also been documented using observations [42-47] and GCMs [27-29,48-51]. From these, a consensus emerged in that rainfall decrease in the region is linked to the positive phase of ENSO.

Regarding the physical mechanisms involved in the observed ENSO-WAM link [46,52,53], several studies that use sensitivity experiments suggest that, during El Niño events, the high-tropospheric heating over the warm SST region in the tropical Pacific triggers a Kelvin wave throughout the African 
Atlantic sector, which is associated with anomalous subsidence over West Africa. Such a mechanism describes an anomalous Walker-type circulation that remotely connects the Tropical Pacific and West Africa [29,49-51], thus reducing rainfall. In addition, a connection with the anomalies of the large-scale gradient between the SSTs from the west Pacific to the eastern Indian Ocean has also been proposed, by which a stationary equatorial Rossby wave propagating westward induces anomalous subsidence over West Africa [48].

Some works have put forward the non-stationary relationship in time between the ENSO and WAM variability $[27,28,44,46,47,51]$. From the 1970 s to the early 2000 s, the negative correlation between Sahelian rainfall and Pacific SST anomalies has strengthened in comparison to the previous decades [46], as supported by sensitivity experiments done with GCMs [50]. Nevertheless, observational studies do not show this increment [28], maybe because during this period the Pacific acts together with the Atlantic, being anti-correlated during summer [54]. With this configuration, the Atlantic counteracts the effect of the Pacific on the Sahel diminishing the observed impact, a theory that has been further supported through the use of sensitivity experiments [51].

In order to analyze the non-stationary link between ENSO-Sahelian rainfall and its impact on seasonal predictability, the S4CAST model [40] is used in this study. Maximum covariance analysis (MCA) between SST anomalies in the tropical Pacific sector $\left(120^{\circ} \mathrm{E}-60^{\circ} \mathrm{W} ; 30^{\circ} \mathrm{S}-20^{\circ} \mathrm{N}\right)$ and anomalous rainfall in the Sahelian domain $\left(18^{\circ} \mathrm{W}-10^{\circ} \mathrm{E} ; 12^{\circ} \mathrm{N}-18^{\circ} \mathrm{N}\right)$ during JAS (July-August-September) is performed to determine the leading mode of co-variability. Each mode of covariability is defined by two spatial structures (for the predictand and predictor variables) and two time series (expansion coefficients) indicating the amplitude of the spatial pattern in each of the time steps. The variability of the expansion coefficients reveals changes in the standard deviation and changes in the correlation between both time series (Figure 1a). Indeed, the 21 year-sliding window correlations between the expansion coefficients of the leading mode (green line) indicates that the relationship changes over time in a significant way. In this way, three different steady periods are determined: (i) the entire period (EP), calculating the MCA for the whole period; (ii) the period with significant correlation (SC); and (iii) the periods with no-significant correlation (NSC). By repeating the MCA for each individual period, the leading co-variability mode shows a percentage of explained variance of $46 \%$, $48 \%$ and $37 \%$, respectively (Figure 1). As a remarkable result, the SC period is mainly restricted to the period from 1950s onwards (Figure 1, top panel), consistent with the previously mentioned works. The leading co-variability mode in terms of regression maps for the same SC period shows a heating in the tropical Pacific related to a decrease in rainfall in the Sahel, as pointed out by several authors (e.g., $[27,28,51]$ ). A cross-validated hindcast for the three periods is done and the correlation between the hindcast rainfall and the observations is shown as a measure of the reliability of the mode in predicting Sahelian rainfall. According to these results, the ability of the leading mode in reproducing rainfall impacts due to ENSO is stronger during the SC period; it decreases during EP, and virtually vanishes for the NSC period.

The correlation curve in Figure 1 evolves as a multidecadal oscillation and indicates the periods in which ENSO teleconnection is stronger over the Sahel. Looking at the ENSO signal, there is no change in its spatial configuration, so it is plausible to think that the slowly varying background state could be modifying the teleconnection mechanism. This result has also been pointed out in Rodríguez-Fonseca et al. [29], where the authors encourage to further explore the multidecadal modulation of teleconnections. The present study confirms the absence of stationarity and its impact on seasonal predictability. 


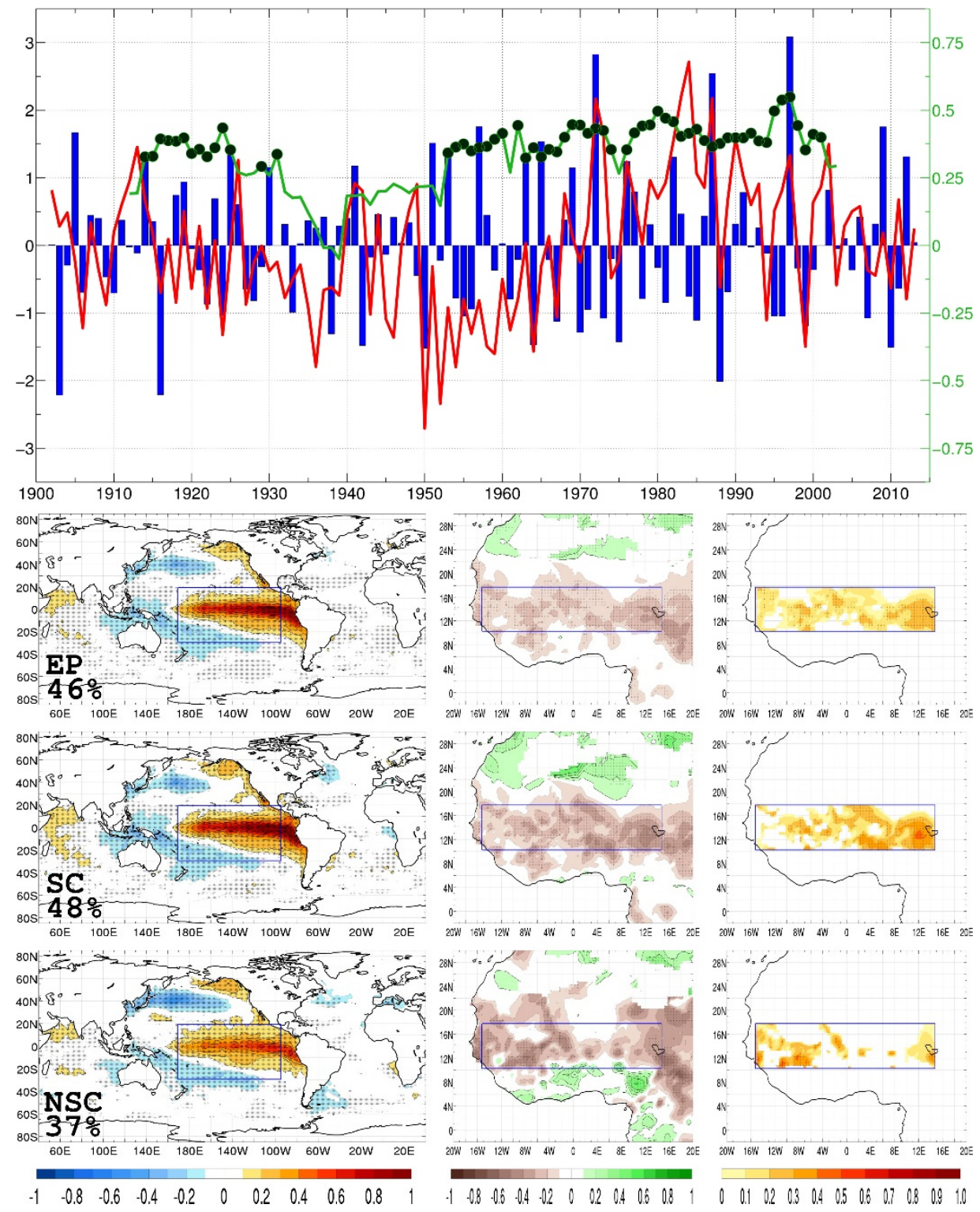

Figure 1. (Top Panel) Expansion coefficients of the leading MCA mode calculated between the anomalies of tropical Pacific SST (blue bars, left axis) and the anomalous Sahelian rainfall (red line, left axis) in JAS. Superimposed, the 21-year centered moving correlation windows (green line, right axis) and significant correlation (black filled circles) between both expansion coefficients; (Bottom Panels): (First) Regression maps of the SST expansion coefficient of the leading MCA mode onto the SST (left) and rainfall (center). Correlation maps (right) between the cross validated hindcast of rainfall performed only with the leading MCA mode. The whole time period is used for the analysis. (Second) As (first) but using the years corresponding to the center of the significant correlation windows (green dots in the green curve). (Third) As (first) and (second) but using the years corresponding to the center of the non-significant correlation windows. The percentage of squared covariance fraction is indicated in the left bottom corner of the figure.

\subsubsection{ENSO Impact on Hurricane Season}

Hurricanes are the primary source of hazardous weather in the Tropical North Atlantic [55-57]. Although the hurricane season starts officially in June and ends in November, the period with greatest activity extends from August to October (ASO; [31,58]). This is due to the seasonal cycle of sea surface temperatures over the Tropical Atlantic corridor $\left(10^{\circ} \mathrm{N}-20^{\circ} \mathrm{N}, 80^{\circ} \mathrm{N}-20^{\circ} \mathrm{W}\right)$, also known as the 
Main Development Region (MDR). Over the North Atlantic, tropical cyclones generally form from African Easterly waves travelling westward into the ocean [59,60]. If African Easterly Waves enter the MDR during late summer or early autumn, they are more likely to encounter SSTs promoting deep convection $\left(>26^{\circ} \mathrm{C} ;[61]\right)$. Such conditions, in conjunction with a weak vertical wind shear environment (v250-v850 hPa $<\sim+8 \mathrm{~m} / \mathrm{s}$ ), are known to foster strong tropical cyclone intensification [32,60]. In fact, $85 \%$ of major Atlantic hurricanes develop from African easterly waves over the MDR [59].

At interannual timescales, the positive (negative) phase of ENSO is associated with a significant enhancement (decrease) of vertical wind shear over large parts of the MDR, especially over and around the Caribbean Sea (Figure 2a; $[62,63]$ ). Thus, a reduction in hurricane activity is observed during the onset years of El Niño, and the contrary during La Niña [64-66]. Other factors such as the ENSO influence on the Western African Monsoon, African Easterly Waves and the intensity of the Azores high also contribute to the strong interannual variability of Atlantic hurricane activity $[1,67,68]$. The estimated influence of the ENSO decay phase on the following ASO hurricane season is much more reduced than for the ENSO onset [64,69].

(a) ENSO influence on Hurricane development

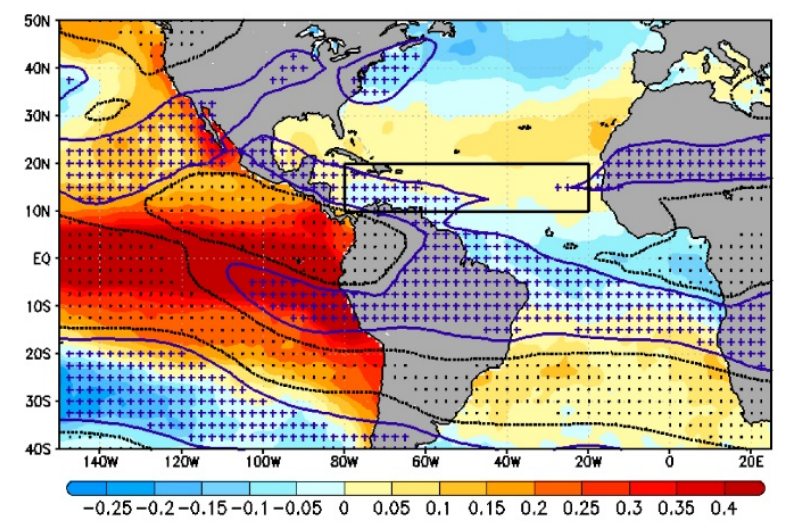

(b) Atlantic Hurricane Activity vs. ENSO \& AMO

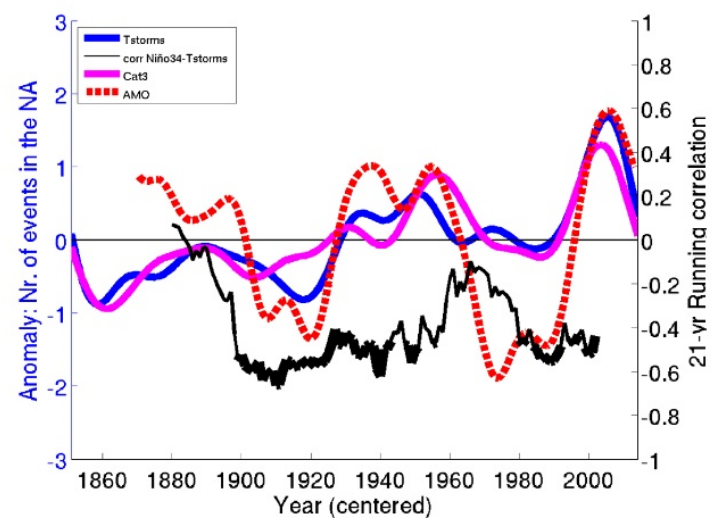

Figure 2. (a) Previous August-October SSTs (red/blue shadings in $\mathrm{K} \cdot \mathrm{std}^{-1}$ ) and vertical $850-250 \mathrm{hPa}$ wind shear (black/purple contour values at $\pm 0.5 \mathrm{~m} \cdot \mathrm{s}^{-1} \cdot \mathrm{std}^{-1}$ ) regressed onto Niño 3.4 index (December-February). Statistically significant areas of enhanced/reduced wind shear marked with crosses/dots (95\% confidence interval). The Atlantic Hurricane Main Development Region is shown in a black rectangle; (b) Anomaly from long term mean: Number of Tropical Storms and Hurricanes over the North Atlantic (June to November, blue and magenta lines-11 years smoothing). The Atlantic Multidecadal Oscillation index (red dashed line). Twenty-one-year running correlations (centered) between Tropical Storm activity (hurricanes included) and Niño 3.4 index (black line). There is a 95\% confidence interval ( $t$ test) in thicker segments. Data sources: HURDAT2, HadISST and NCEP.

At longer timescales, several studies have shown that hurricanes appear to be influenced by natural multidecadal variability of the climate system (Figure 2b; [70-73] and/or global warming [74-76]). However, to our knowledge, no attempt has been made so far to understand the role of multidecadal variability (fundamentally the Atlantic Multidecadal Oscillation, AMO [77]) on the ENSO-hurricanes interannual teleconnection. Thus, the stationarity of ENSO influence on hurricane activity is shown in Figure 2b, where the 21-year running correlation curve between Niño 3.4 index and tropical cyclone activity is provided together with the AMO index. The moving correlation curve depicts an apparent non-stationary connection. The link is statistically significant after the 1970s, and weaker during the three decades before. Also, a strong anti-correlation period appears at the beginning of the 20th century. However, it is not evident from Figure $2 b$ that AMO itself plays a fundamental role on the multidecadal modulation of the ENSO-hurricanes interannual teleconnection. In Figure $2 b$, significant negative correlation exists during both the positive and negative polarity 
of the AMO. Nevertheless, these results must be considered with caution because the HURDAT2 dataset is less reliable on pre-satellite decades $[59,62,78-80]$. These results are in agreement with Giannini et al. [81], where it is shown that a developing positive ENSO phase leads to a reduction in rainfall over the Caribbean region. Such teleconnection is found to be stronger after the 1970s, and may be associated with a stronger than average North Atlantic Anticyclone, which in turn reduces convection over the Caribbean sea area.

\subsection{ENSO Influence on the Extratropical North Atlantic}

Regarding the dynamics associated with the ENSO impact on the NAE rainfall, several mechanisms have been proposed, including tropospheric and stratospheric pathways. These mechanisms, together with their stationarity and the influence of multidecadal ocean variability, are discussed in the next sections. The impact on predictability is also analyzed using the S4CAST model.

\subsubsection{Tropospheric Mechanisms of ENSO Impact on the European Region}

The tropospheric mechanisms of ENSO teleconnection in the extratropics include the alteration of both the overturning divergent circulation and the non-divergent flow. On the one hand, it is well known that El Niño (La Niña) enhances (decreases) air subsidence over the Equatorial Atlantic and thus weakens (reinforces) both the Walker and the Atlantic Hadley circulations [82,83]. As a consequence, the Azores high and the related westerlies are altered, and so is the climate variability over the NAE. This impact seems to depend on SSTs over the TNA [84-87], especially in late winter $[88,89]$. On the other hand, the most accepted tropospheric mechanism implies the alteration of the Aleutian low through changes in the Pacific Hadley circulation in early and mid-winter, and then, via downstream propagation of large-scale Rossby wave-trains [16,90] and synoptic-scale waves over North America [91-95]. In January, the Tropical Northern Hemisphere pattern (TNH; consistent of three centers of actions along the North Pacific-American sector; [96-99]) is completely established [100]. This is accompanied by a split of the Rossby wave-train impacting Eurasia [101]. The resulting quasi-barotropic structure represents the leading rotational mode of upper level streamfunction in the NAE region [3].

As stated in the previous section, the ENSO impact on the North Atlantic seems to be non-stationary in time. This issue can be partially explained by changes in the ocean mean state, but also by alterations in ENSO amplitude and structure [87,102], which are modulated by multidecadal SST variability [103]. On the one hand, according to the thermal wind equation, positive meridional temperature gradients act to strengthen the upper level jets. Under a negative AMO, regions with negative meridional gradients are associated with a weakened jet, thus fostering the propagation of ENSO related Rossby waves. On the other hand, the existence of distinct ENSO patterns (more eastern/western located) depending on the decade considered [104-110], acts to change the region of the ENSO-related Rossby waves, and thus, their associated impacts.

In relation to the changes in the mean state, the modification of the conditions of the upper tropospheric jets and Rossby waveguides can also modify the ENSO-related planetary wave propagation from the tropical Pacific towards the NAE sector. This mechanism holds differently for the so-called Eastern and Central Pacific ENSO episodes [111], and seems to be modulated by natural multidecadal SST anomalies [21,22].

Also in this context, a recent study from Gómara et al. [26] points to a potential non-stationary connection between ENSO and explosive North Atlantic cyclones [112]. Through the use of cyclone track density winter data on NCEP, ERA-40 and a long control simulation (ECHAM5/MPIOM1), they find a non-stationary influence of ENSO on the leading interannual mode of explosive North Atlantic cyclones. In reanalysis, this teleconnection is distinguishable between the mid and late 20th century [23]. In the GCM, the teleconnection is significant and robust for most of the time period, with the exception of two specific intervals of several decades when it vanishes. Although further analyses need to be done in this line, these results are also consistent with the existence of multidecadal changes in the ENSO-North Atlantic teleconnection. 
In fall, a negative NAO-like pattern is related to ENSO, though this relationship is non-stationary and changes depending on the considered decades. In this way, López-Parages and Rodríguez-Fonseca [20] suggest that the ENSO influence seems to be modulated by the Interdecadal Pacific Oscillation (IPO). Whereas for some decades El Niño is related to a negative NAO-like signature, in others the signature is the opposite.

In summer, some authors point to a weak impact of ENSO over the Euro-Mediterranean region, which can lead to local rainfall anomalies [113,114]. These anomalies occur (especially after the 1970s) together with a negative NAO-like configuration and negative SST anomalies over the North Pacific. As a consequence, Rossby waves triggered from the Pacific are able to reach more efficiently the western North Atlantic.

In the same context, other authors suggest a multidecadal modulation of the ENSO impact in the summer circumglobal teleconnection pattern (CGT), via changes in its coupling to the Indian Summer Monsoon (ISM; [115]). According to these results, the weakening in the ENSO-ISM coupling after the 1970s leads to a weakening of the CGT centers of action, especially over the North Atlantic and Europe. The CGT has been linked with a west-east dipole of anomalous precipitation over Europe [116], thus pointing to a multidecadal modulation of the ENSO impact on European precipitation in summer through changes in the CGT pattern.

Finally, the mentioned non-stationarities in this section are also reflected in bio-climatic indices. Capa-Morocho et al. [117] have recently found that summer maize yield variability over northwestern Iberia is highly linked to El Niño, with opposite impacts depending on the decades considered. Rozas et al. [118] suggest, also for summer, a significant positive link between the growth of beeches over Northern Iberian Peninsula and Niño 3.4 index. As explained by the authors, such strengthened connection is due to the increased late spring and early summer cloudiness under El Niño conditions, which act to mitigate temperature and rainfall stresses for beech growth.

\subsubsection{Stratospheric Mechanisms of ENSO Impact on the European Region}

A two-step pathway relates ENSO to North Atlantic climate via the polar stratosphere in winter. The first part of the pathway concerns an ENSO-polar vortex negative relationship consisting in the excitation of the Pacific North American pattern (PNA; e.g., [119,120]) that leads to the amplification of the stationary zonal wavenumber-1 wave during the El Niño (EN) phase $[119,121]$. The amplified wave activity propagates upward and breaks at stratospheric levels, warming the polar stratosphere and weakening the vortex (e.g., [121,122]). The opposite happens under La Niña (LN) conditions. However, the seasonal mean response of the polar vortex to EN and LN does not agree with a higher frequency of extreme weak or strong polar vortex events, respectively. In fact, a higher frequency of major stratospheric warmings (MSWs, extreme weak vortex events) for both EN and LN events is found than under neutral ENSO conditions [123,124]. The second part of the pathway concerns the downward propagation of the ENSO-induced stratospheric anomalies to the troposphere. In general, extreme warm (cool) anomalies in the polar stratosphere descend in wintertime and project onto a negative (positive) phase of the NAO, affecting the NAE climate [5]. ENSO-induced polar stratospheric anomalies also propagate downward (e.g., $[18,125])$, but only when a MSWs occurs [126,127]. Additionally, Butler et al. [128] have recently suggested that this stratospheric pathway would result in a tropospheric pattern of the same sign for both EN and LN events, since it is due to the stratospheric anomalies associated with MSWs. Nevertheless, there is still high uncertainty in the processes involved in this stratospheric pathway.

Only a few studies have analyzed the stationarity of the stratospheric signal, by extending the study of the stratospheric pathway to the stratospheric response to the new type of ENSO (Central Pacific (CP) ENSO) (e.g., [111,129-131]). Several studies have shown that the effect of CP ENSO on the boreal polar stratosphere is weaker than that corresponding to the canonical one and, consequently, its connection with European weather through the stratospheric pathway is also less 
important $[88,111,129]$. However, Hurwitz et al., [130] have not found any significant difference in the stratospheric response to ENSO between canonical and CP flavors in CMIP5 models.

To further analyze the possible non-stationarity of the ENSO stratospheric pathway, the polar stratospheric state associated with the first co-variability mode of European precipitation (pcp) and tropical Pacific SSTs in late winter-spring (February-March-April, FMA) is analyzed by means of NCEP/NCAR reanalysis data [38]. In agreement with López-Parages et al. [21]; (cf. Section 3.2.3), periods with strong and positive ( $\mathrm{P}$ period) and weak and negative relationships ( $\mathrm{N}$ period) between Pacific SSTs and European rainfall are found. The use of reanalysis data restricts the intervals to 1965-1984 and 1949-1964/2003-2008 as representative of positive and negative periods. Our results show that the stratospheric pathway in the P period plays a more important role in the European rainfall response to ENSO than in the $\mathrm{N}$ period.

First, the polar vortex in P period is anomalously weak during the whole winter in association with a warming of the equatorial Pacific (Figure 3a). In contrast, in N period (Figure 3e), the middle polar stratosphere is only significantly disturbed in January-February-March (JFM) and February-March-April (FMA) averages. The difference in the intensity of the signal in the polar stratosphere between periods may be explained by a discrepancy in the intensity and persistence of the tropospheric forcing (Figure $3 \mathrm{~b}-\mathrm{d}, \mathrm{f}-\mathrm{h}$ ). In particular, whereas a strong deepening of the tropospheric Aleutian low appears during October-November-December (OND) in the P period (Figure 3b), this is much weaker and not detected until December-January-February (DJF) in the N period (Figure 3g). In addition, the location of the center of geopotential height $(Z)$ anomalies at $500 \mathrm{hPa}$ close to the Aleutian low is different in both periods, being westward shifted in $\mathrm{N}$ relative to $\mathrm{P}$. This shift might have an effect on the interference of the anomalous wavenumber- 1 wave with the climatological one. The spatial shift is also consistent with a similar displacement in the region of the strongest warming in the equatorial Pacific SSTs. In fact, these results agree with those derived by Zubiaurre and Calvo [129] about the timing and intensity of tropospheric forcing of CP ENSO.

Secondly, the mentioned polar stratospheric anomalies of the $\mathrm{P}$ period descend during winter, being statistically significant along the whole stratosphere in FMA (Figure 3a). Positive anomalies of geopotential height $(\mathrm{Z})$ at polar cap in the positive phase of the mode also reach the lower troposphere in JFM, but are not statistically significant. Nevertheless, despite this lack of statistical significance in the troposphere, there is a connection between the ENSO-induced extratropical stratospheric $\mathrm{Z}$ anomalies and the SLP anomalies in the NAE sector $\left(90^{\circ} \mathrm{W}-40^{\circ} \mathrm{E}, 30^{\circ}-90^{\circ} \mathrm{N}\right)$. The correlation between an index of the NAE SLP anomalies in FMA related to the changes in tropical SSTs and another index of the ENSO-induced extratropical $\mathrm{Z}$ anomalies at $10 \mathrm{hPa}$ in the same months is 0.86 . The correlation remains mostly the same when leading the $\mathrm{Z}$ index one month and is still statistically significant with a lag of two months at a $95 \%$ confidence level (0.68). In the case of the $N$ period, the positive polar cap $\mathrm{Z}$ anomalies in Figure 3e do not even reach the lower stratosphere. The correlation of the NAE SLP in FMA and stratospheric indices in different months is not statistically significant in any given case at a 95\% confidence level (FMA: 0.40; JFM: -0.06; DJF: 0.22).

To confirm the important role of the stratosphere during P period in the ENSO-European pcp teleconnection and since the downward propagation of ENSO-induced stratospheric anomalies has been linked to the occurrence of MSWs, we have computed the frequency of MSWs associated with the extreme events of the European pcp in FMA linked to changes in tropical Pacific SSTs. The extreme events have been identified as those cases where the expansion coefficient of the pcp of the first co-variability mode between tropical SSTs and European pcp is larger than 0.75 standard deviation in absolute value. In the case of $\mathrm{P}$ period, $60 \%$ of extreme events are preceded by the occurrence of a MSW. The probability is even higher (4 out of 5) for events of the positive phase, i.e., higher pcp than normal in Central Europe and close to the pattern associated with the negative phase of the North Atlantic Oscillation [132]. Regarding the N period, only $42 \%$ of extreme events of European pcp follow MSWs and there is not a predominant phase among them. These results agree well with previous 
authors such as Ineson and Scaife [133] or Cagnazzo and Manzini [127], who highlight the importance of a MSW for the downward propagation of ENSO-induced stratospheric anomalies.

Finally, we have also found that the link between the ENSO and polar stratospheric anomalies is only statistically significant in the P period regardless of the European pcp (Figure 3i). In fact, Figure 3i shows that only statistically significant correlations are found in the time windows corresponding to P period.
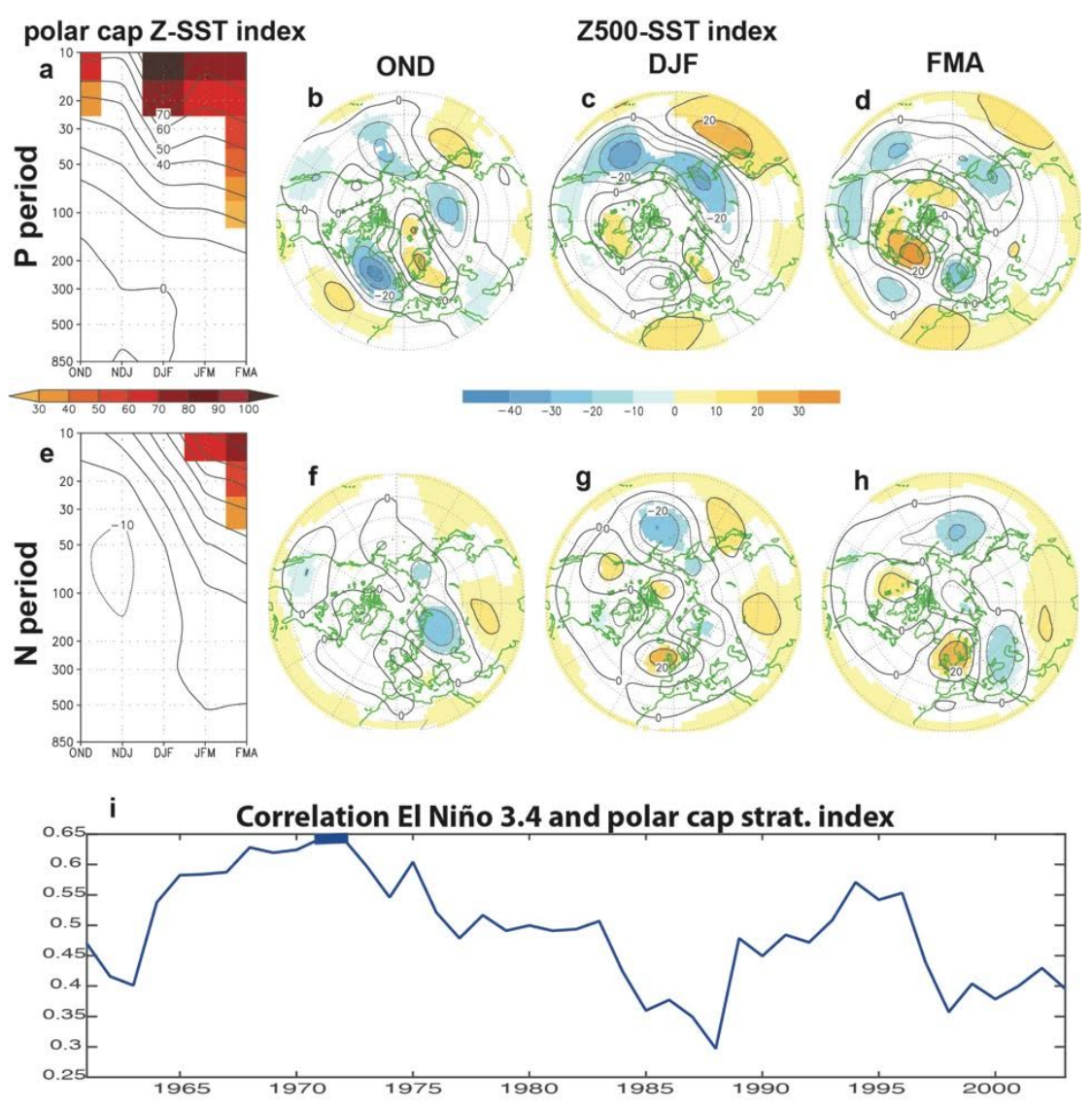

Figure 3. Analysis of the stratospheric pathway of ENSO-European weather teleconnection. (a-d) Regression maps of different anomalous 7-year high-pass filtered fields on the SST expansion coefficient of the first co-variability mode of the tropical SSTs and the European rainfall in FMA for the $P$ period: (a) Area-averaged geopotential height over the polar cap $\left(90^{\circ}-60^{\circ} \mathrm{N}\right)$ in different months (from OND to FMA) (contour interval: $10 \mathrm{~m}$ ); (b-d) Geopotential height at $500 \mathrm{hPa}$ in OND, DJF and FMA, respectively (contour interval: $10 \mathrm{~m}$ ); (e-h) Same as (a-d) but for the N period. Shadings correspond to statistically significant correlations between the SST index and the Z anomalies at a $95 \%$ confidence level (Monte-Carlo test with 400 permutations); (i) 20-year centered moving correlation windows between the 7-year high-pass filtered geopotential anomalies at $10 \mathrm{hPa}$ and averaged over the polar cap $\left(90^{\circ} \mathrm{N}-60^{\circ} \mathrm{N}\right)$ in DJF and the 7-year high-pass filtered SST anomalies over the El Niño 3.4 area in the same months. Thick line indicates statistically significant values at a $90 \%$ confidence level (Monte-Carlo test with 400 permutations).

\subsubsection{Impact of ENSO on Anomalous Rainfall}

Regardless of the mechanisms through which ENSO teleconnection is established over the extratropics, the ENSO signature on European and Mediterranean rainfall has changed across the 20th century [134,135], a feature that confirms the absence of stationarity in the ENSO response. As stated before, some authors have attributed this changing impact to the influence on the atmospheric mean state of well-known multidecadal SST modes such as the AMO and the Interdecadal Pacific Oscillation (IPO, [20,136]). 
This seems to be crucial for those regions where the skill of seasonal forecasting systems is still poor, as is the case of Europe and the Mediterranean region. As a consequence, windows of opportunity for the enhancement of these currently complicated seasonal predictions could be opened, at least, for certain decades.

To illustrate this point, the S4CAST model has been applied during late winter and early spring (FMA) to determine the reliability of the tropical Pacific for seasonal predictability of European rainfall. In this way, Figure 4 depicts the leading co-variability mode between Pacific SSTs and European rainfall described in López-Parages et al. [21]. The correlation between the expansion coefficients identifies a change in the teleconnection, with periods of strong rainfall response and positive correlation between Niño 3.4 index and rainfall (P periods: 1900-1940/1965-1984; consistent with López-Parages et al. [21]) and periods when this signal is weak and not statistically significant (N period: 1944-1964/2003-2008).

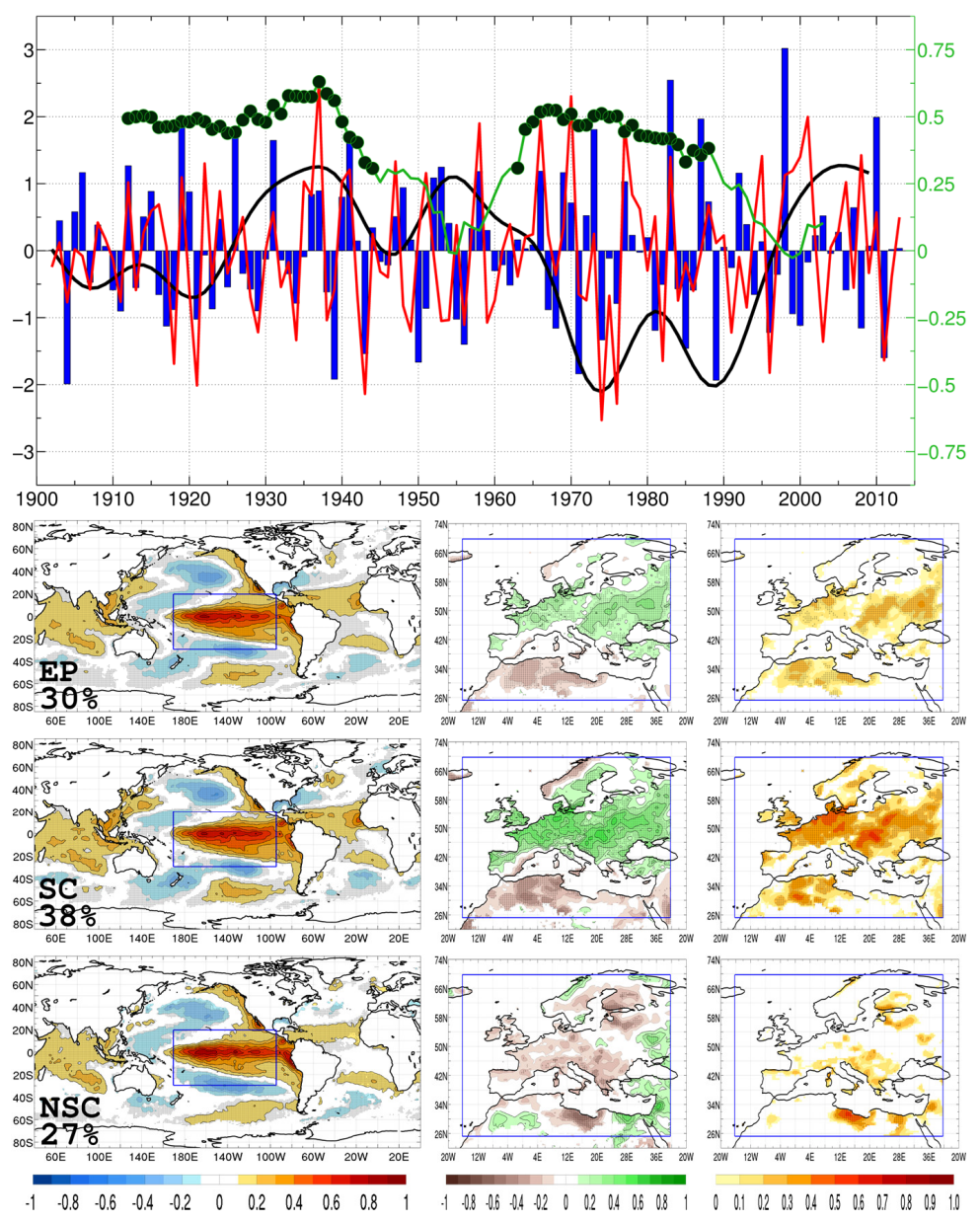

Figure 4. (Top Panel) Expansion coefficients of the leading MCA mode calculated between the anomalies of tropical Pacific SST (blue bars, left axis) and the anomalous Euro-Mediterranean rainfall (red line, left axis) in FMA. Superimposed, the 21-year centered moving correlation windows (green line, right axis) and significant correlation (black filled circles, right axis) between both expansion coefficients. The black curve corresponds to the AMO index; (Bottom Panels) (First) Regression maps of the SST expansion coefficient of the leading MCA mode onto the SST (left) and rainfall (center); Correlation maps (right) between the cross validated hindcast of rainfall performed only with the leading MCA mode. The whole time period is used for the analysis. (Second) As (first) but using the years corresponding to the center of the significant correlation windows (green dots in the green curve). (Third) As (first) and (second) but using the years corresponding to the center of the non-significant correlation windows. The percentage of squared covariance fraction is indicated in the left bottom corner of the figure. 
The evolution of the correlation presents some similarities to that found for the influence of ENSO on Sahel rainfall variability in summer. The capability of the rainfall hindcast is plotted in terms of correlation maps, showing that it significantly increases in the same periods that the ENSO response over the Sahel is stronger.

\section{Discussion and Conclusions}

The present paper has reviewed and further addressed different El Niño-Southern Oscillation (ENSO) teleconnections over the Atlantic basin, finding interesting coincidences about their temporal non-stationarities. In this context, correlation curves from Figures 1-3 depict very similar results despite the regions, seasons, and variables used are different. In general, distinct ENSO-related impacts are found before and after the 1970s over the Atlantic basin. Some correlation curves appear to evolve in phase with the Atlantic Multidecadal Oscillation (AMO). As a consequence, during decades of negative AMO, the occurrence of ENSO increases the forecast ability of winter European and tropical rainfall. On the contrary, during the periods of positive AMO the ENSO's impacts are almost negligible over the Atlantic and no further ability can be added to seasonal forecasts.

Although the AMO seems to be the principal modulating factor, the influence of other patterns, such as the Interdecadal Pacific Oscillation or Global Warming, has been suggested in the literature $[20,115]$. For the case of the North Atlantic European (NAE) region, Capa-Morocho et al. [115] found a stronger ENSO-NAE teleconnection when both the AMO and IPO coincide under same phase (for instance, the period 1960-1980).

A remarkable feature that guarantees the robustness of our results is the existence of different non-stationary ENSO impacts, all of which appear consistent in time regardless of the variables, seasons and regions chosen for the analysis.

The presence of non-stationarities can be due to different potential reasons. First, climate anomalies over the Northern Hemisphere can be understood as a linear combination of teleconnections associated with changes in the zonal mean flow and the ENSO states [137]. This could explain the different dynamical mechanism associated with the ENSO forcing in each of the periods. Over the European region, López-Parages et al. [22] have recently demonstrated using sensitivity General Circulation Model (GCM) experiments that different background states (e.g., global SSTs during negative or positive AMO) associated with the same El Niño pattern can produce distinct teleconnections. In particular, the ENSO impact over Europe is better established during the negative AMO decades, in which a southward shift of the Intertropical Convergence Zone (ITCZ) produces changes in the jetstream configuration and, thus, in the wave-propagation pathways. In this line, the role of decadal variability in the timing and seasonal establishment of teleconnections remains as an interesting topic for future research.

Secondly, another possible reason for the non-stationarity is the presence of concomitant SST anomalies in other ocean basins associated with El Niño events in negative AMO periods [138]. Such SST anomalies in other basins could counteract the effect of El Niño over the North Atlantic and Sahel. This was stated in Losada et al. [51] for the case of the ENSO influence in the West African Monsoon after the 1970s when equatorial Atlantic anomalies counteract the effect of the Pacific; as well as Losada et al. [139] for the response of summer Mediterranean climate to tropical SST anomalies.

A third possible reason can be related to the amplitude of the ENSO signal, as some authors have suggested that the ENSO amplitude could vary under different phases of the AMO. In this context, López-Parages et al. [22] have recently shown that changes in the background state are inconsequential if very strong ENSO events are considered. Nevertheless, under realistic ENSO events, changes in the ocean climatology are enough to alter the wave-guides and, thus, teleconnections.

Finally, despite that causality is a challenging topic to undertake in climate variability, most of the results provided in this article are backed by plausible physical mechanisms and confirmed by sensitivity experiments done by existing studies (e.g., [22]). Nevertheless, although results are 
supported by model experiments, they are still constrained by the relatively limited coverage of observational data. Thus, there is a need for sustained observations to resolve multi-decadal variability.

The presents results are crucial not only for the understanding of ENSO teleconnections and associated dynamics and impacts, but also for the current seasonal forecast system, as it opens windows of opportunity for North Atlantic climate predictability.

Acknowledgments: We thank the Climatic Research Unit (CRU), the National Centers for Environmental Prediction (NCEP), the Met Office Hadley Centre and the US National Hurricane Center (NHC) for the Land Precipitation, reanalysis, SST and HURDAT2 datasets, respectively. Belen Rodríguez-Fonseca, Roberto Suárez-Moreno, Jorge López-Parages, Iñigo Gómara, Elsa Mohino, Teresa Losada and Antonio Castaño-Tierno are supported by the research projects PREFACE (EUFP7/2007-2013 Grant Agreement 603521) and MULCLIVAR (CGL2012-38923-C02-01-Spanish Ministry of Economy and Competitiveness). Blanca Ayarzagüena is supported by the Natural Environment Research Council (grant number NE/M006123/1). Julián Villamayor is granted through a scholarship from the MICINN-Spanish government (BES-2013-063821). Finally, we would like to thank the two anonymous reviewers for their pertinent comments and suggestions, which have contributed to improve this manuscript.

Author Contributions: Belen Rodríguez-Fonseca has led/designed/written the article and performed simulations with the S4CAST model. Roberto Suárez-Moreno has developed the S4CAST model, performed simulations and written Section 3.1.1. Blanca Ayarzagüena has been in charge of Section 3.2.2 and associated items. Jorge López-Parages has contributed in Sections 3.2.1 and 3.2.3. Iñigo Gómara has developed Section 3.1.2 and associated contents. Julián Villamayor has contributed writing Section 3.1.1. Elsa Mohino, Teresa Losada and Antonio Castaño-Tierno have helped with the writing and reviewing of the manuscript. All authors have collaborated in the discussion of the main items of the paper.

Conflicts of Interest: The authors declare no conflict of interest.

\section{Abbreviations}

The following abbreviations are used in this manuscript:

\begin{tabular}{ll} 
AMO & Atlantic Multidecadal Oscillation \\
CGT & Circumglobal Teleconnection Pattern \\
CP & Central Pacific \\
CRU & Climate Research Unit \\
EN & El Niño \\
ENSO & El Niño-Southern Oscillation \\
EP & Entire Period \\
GCM & General Circulation Model \\
HURDAT & Atlantic Hurricane Database \\
IPO & Interdecadal Pacific Oscillation \\
ISM & Indian Summer Monsoon \\
ITCZ & Intertropical Convergence Zone \\
LN & La Niña \\
MCA & Maximum Covariance Analysis \\
MDR & Main Development Region \\
MSW & Major Stratospheric Warming \\
NAE & North Atlantic European region \\
NAO & North Atlantic Oscillation \\
NCAR & National Center for Atmospheric Research \\
NCEP & National Centers for Environmental Prediction \\
NSC & No-Significant Correlation \\
pcp & Precipitation \\
PNA & Pacific North American pattern \\
SC & Significant Correlation \\
SLP & Sea Level Pressure \\
SST & Sea Surface Temperature \\
S4CAST & SST-based Statistical Seasonal Forecast model \\
TNA & Tropical North Atlantic \\
TNH & Tropical Northern Hemisphere \\
WAM & West African Monsoon \\
Z & Geopotential Height \\
& \\
\hline
\end{tabular}




\section{References}

1. Brönnimann, S. Impact of El Niño-Southern Oscillation on European climate. Rev. Geophys. $2007,45$. [CrossRef]

2. Hurrell, J.W.; Deser, C. North Atlantic climate variability: The role of the North Atlantic Oscillation. J. Mar. Syst. 2010, 79, 231-244. [CrossRef]

3. García-Serrano, J.; Rodríguez-Fonseca, B.; Bladé, I.; Zurita-Gotor, P.; Cámara, A. Rotational atmospheric circulation during North Atlantic-European winter: The influence of ENSO. Clim. Dyn. 2011, 37, 1727-1743. [CrossRef]

4. Bladé, I.; Liebmann, B.; Fortuny, D.; van Oldenborgh, G.J. Observed and simulated impacts of the summer NAO in Europe: Implications for projected drying in the Mediterranean region. Clim. Dyn. 2012, 39, 709-727. [CrossRef]

5. Baldwin, M.P.; Dunkerton, T.J. Stratospheric harbingers of anomalous weather regimes. Science 2001, 294, 581-584. [CrossRef] [PubMed]

6. Alheit, J.; Bakun, A. Population synchronies within and between ocean basins: Apparent teleconnections and implications as to physical-biological linkage mechanisms. J. Mar. Syst. 2010, 79, 267-285. [CrossRef]

7. Franzke, C.; Lee, S.; Feldstein, S.B. Is the North Atlantic Oscillation a breaking wave? J. Atmos. Sci. 2004, 61, 145-160. [CrossRef]

8. Woollings, T.; Hoskins, B.; Blackburn, M.; Berrisford, P. A New Rossby Wave-breaking Interpretation of the North Atlantic Oscillation. J. Atmos. Sci. 2008, 65, 609-626. [CrossRef]

9. Strong, C.; Magnusdottir, G. Tropospheric Rossby wave breaking and the NAO/NAM. J. Atmos. Sci. 2008, 65, 2861-2876. [CrossRef]

10. Trenberth, K.E. The Definition of El Niño. Bull. Am. Meteorol. Soc. 1997, 78, 2771-2777. [CrossRef]

11. Van Loon, H.; Madden, R.A. The Southern Oscillation. Part I: Global associations with pressure and temperature in northern winter. Mon. Weather Rev. 1981, 109, 1150-1162. [CrossRef]

12. Hamilton, K. A detailed examination of the extratropical response to tropical El Niño/Southern Oscillation events. J. Climatol. 1988, 8, 67-86. [CrossRef]

13. Kiladis, G.N.; Diaz, H.F. Global climatic anomalies associated with extremes in the Southern Oscillation. J. Clim. 1989, 2, 1069-1090. [CrossRef]

14. Fraedrich, K.; Müller, K. Climate anomalies in Europe associated with ENSO extremes. Int. J. Climatol. 1992, 12, 25-31.

15. Fraedrich, K. An ENSO impact on Europe? Tellus A 1994, 46, 541-552. [CrossRef]

16. Moron, V.; Plaut, G. The impact of El Nino-southern oscillation upon weather regimes over Europe and the North Atlantic during boreal winter. Int. J. Climatol. 2003, 23, 363-379. [CrossRef]

17. Van Loon, H.; Labitzke, K. The Southern Oscillation. Part V: The anomalies in the lower stratosphere of the Northern Hemisphere in winter and a comparison with the quasi-biennial oscillation. Mon. Weather Rev. 1987, 115, 357-369. [CrossRef]

18. Manzini, E.; Giorgetta, M.A.; Esch, M.; Kornblueh, L.; Roeckner, E. The influence of sea surface temperatures on the northern winter stratosphere: Ensemble simulations with the MAECHAM5 model. J. Clim. 2006, 19, 3863-3881. [CrossRef]

19. García-Herrera, R.; Calvo, N.; García, R.R.; Giorgetta, M.A. Propagation of ENSO temperature signals into the middle atmosphere: A comparison of two general circulation models and ERA-40 reanalysis-data. J. Geophys. Res. 2006, 111. [CrossRef]

20. López-Parages, J.; Rodríguez-Fonseca, B. Multidecadal modulation of El Niño influence on the Euro-Mediterranean rainfall. Geophys. Res. Lett. 2012, 39. [CrossRef]

21. López-Parages, J.; Rodríguez-Fonseca, B.; Terray, L. A mechanism for the multidecadal modulation of ENSO teleconnection with Europe. Clim. Dyn. 2014, 45, 867-880. [CrossRef]

22. López-Parages, J.; Rodríguez-Fonseca, B.; Dommenget, D.; Frauen, C. ENSO influence on the North Atlantic European climate: A non-linear and non-stationary approach. Clim. Dyn. 2015. [CrossRef]

23. Luksch, U.; Raible, C.C.; Blender, R.; Fraedrich, K. Decadal cyclone variability in the North Atlantic. Meteorol. Z. 2005, 14, 747-753. [CrossRef]

24. Raible, C.C.; Lehner, F.; Gonzalez-Rouco, J.F.; Fernandez-Donado, L. Changing correlation structures of the Northern Hemisphere atmospheric circulation from 1000 to 2100 AD. Clim. Past 2014, 10, 537-550. [CrossRef] 
25. Hertig, E.; Beck, C.; Wanner, H.; Jacobeit, J. A review of non-stationarities in climate variability of the last century with focus on the North Atlantic-European sector. Earth-Science Rev. 2015, 147, 1-17. [CrossRef]

26. Gómara, I.; Rodríguez-Fonseca, B.; Zurita-Gotor, P.; Ulbrich, S.; Pinto, J.G. Abrupt transitions in the NAO control of explosive North Atlantic cyclone development. Clim. Dyn. 2016. [CrossRef]

27. Mohino, E.; Rodríguez-Fonseca, B.; Losada, T.; Gervois, S.; Janicot, S.; Bader, J.; Ruti, P.; Chauvin, F. Changes in the interannual SST-forced signals on West African rainfall. AGCM intercomparison. Clim. Dyn. 2011, 37, 1707-1725. [CrossRef]

28. Rodríguez-Fonseca, B.; Janicot, S.; Mohino, E.; Losada, T.; Bader, J.; Caminade, C.; Voldoire, A. Interannual and decadal SST- forced responses of the West African monsoon. Atmos. Sci. Lett. 2011, 12, 67-74. [CrossRef]

29. Rodríguez-Fonseca, B.; Mohino, E.; Mechoso, C.R.; Caminade, C.; Biasutti, M.; Gaetani, M.; García-Serrano, J.; Vizy, E.K.; Cook, K.; Xue, Y.; et al. Variability and Predictability of West African Droughts. A review on the role of Sea Surface Temperature Anomalies. J. Clim. 2015. [CrossRef]

30. Philander, S.G. El Niño, la Niña, and the Southern Oscillation; Academic Press: San Diego, CA, USA, 1989.

31. Cry, G.W. Effects of Tropical Cyclone Rainfall on the Distribution of Precipitation Over the Eastern and Southern United States; Professional Paper 1; United States Department of Commerce, Environmental Sciences Services Administration: Washington, DC, USA, 1967; p. 67.

32. Emanuel, K.A. Increasing destructiveness of tropical cyclones over the past 30 years. Nature 2005, 436, 686-688. [CrossRef] [PubMed]

33. Rappaport, E. Inland Flooding. National Hurricane Center website 2008. Available online: http://www.nhc. noaa.gov/HAW2/english/inland_flood.shtml (accessed on 10 July 2008).

34. Barlow, M. Influence of hurricane-related activity on North American extreme precipitation. Geophys. Res. Lett. 2011, 38. [CrossRef]

35. Harris, I.; Jones, P.D.; Osborn, T.J.; Lister, D.H. Updated high-resolution grids of monthly climatic observations-The CRU TS3.10 Dataset. Int. J. Climatol. 2014, 34, 623-642. [CrossRef]

36. Rayner, N.A.; Parker, D.E.; Horton, E.B.; Folland, C.K.; Alexander, L.V.; Rowell, D.P.; Kent, E.C.; Kaplan, A. Global analyses of sea surface temperature, sea ice, and night marine air temperature since the late nineteenth century. J. Geophys. Res. 2003, 108. [CrossRef]

37. Landsea, C.W.; Franklin, J.L. Atlantic hurricane database uncertainty and presentation of a new database format. Mon. Weather Rev. 2013, 141, 3576-3592. [CrossRef]

38. Kalnay, E.; Kanamitsu, M.; Kistler, R.; Collins, W.; Deaven, D.; Gandin, L.; Iredell, M.; Saha, S.; White, G.; Woollen, J.; et al. The NCEP/NCAR 40-year reanalysis project. Bull. Am. Meteorol. Soc. 1996, 77, 437-471. [CrossRef]

39. Wilks, D.S. Statistical Methods in the Atmospheric Sciences, 2nd ed.; Elsevier Inc.: Amsterdam, The Netherlands, 2006.

40. Suárez-Moreno, R.; Rodríguez-Fonseca, B. S4CAST v2.0: Sea surface temperature based statistical seasonal forecast model. Geosci. Model Dev. 2015, 8, 3639-3658. [CrossRef]

41. Villamayor, J.; Mohino, E. Robust Sahel drought due to the Interdecadal Pacific Oscillation in CMIP5 simulations. Geophys. Res. Lett. 2015, 42, 1214-1222. [CrossRef]

42. Folland, C.K.; Palmer, T.N.; Parker, D.E. Sahel rainfall and worldwide sea temperatures, 1901-1985. Nature 1986, 320, 602-607. [CrossRef]

43. Palmer, T.N. Influence of the Atlantic, Pacific and Indian oceans on Sahel rainfall. Nature 1986, 322, $251-253$. [CrossRef]

44. Janicot, S.; Moron, V.; Fontaine, B. Sahel droughts and ENSO dynamics. Geophys. Res. Lett. 1996, 23, 515-518. [CrossRef]

45. Janicot, S.; Harzallah, A.; Fontaine, B.; Moron, V. West African monsoon dynamics and eastern equatorial Atlantic and Pacific SST anomalies (1970-1988). J. Clim. 1998, 11, 1874-1882. [CrossRef]

46. Janicot, S.; Trzaska, S.; Poccard, I. Summer Sahel-ENSO teleconnection and decadal time scale SST variations. Clim. Dyn. 2001, 18, 303-320. [CrossRef]

47. Fontaine, B.; Trzaska, S.; Janicot, S. Evolution of the relationship between near global and Atlantic SST modes and the rainy season in West Africa: Statistical analyses and sensitivity experiments. Clim. Dyn. 1998, 14, 353-368. [CrossRef]

48. Rowell, D.P. Teleconnections between the tropical Pacific and the Sahel. Q. J. R. Meteorol. Soc. 2001, 127, 1683-1706. [CrossRef] 
49. Joly, M.; Voldoire, A. Influence of ENSO on the West African monsoon: Temporal aspects and atmospheric processes. J. Clim. 2009, 22, 3193-3210. [CrossRef]

50. Mohino, E.; Rodríguez-Fonseca, B.; Mechoso, C.R.; Gervois, S.; Ruti, P.; Chauvin, F. Impacts of the tropical Pacific/Indian Oceans on the seasonal cycle of the West African monsoon. J. Clim. 2011, 24, 3878-3891. [CrossRef]

51. Losada, T.; Rodriguez-Fonseca, B.; Mohino, E.; Bader, J.; Janicot, S.; Mechoso, C.R. Tropical SST and Sahel rainfall: A non-stationary relationship. Geophys. Res. Lett. 2012, 39. [CrossRef]

52. Giannini, A.; Saravannan, R.; Chang, P. Dynamics of the boreal summer African monsoon in the NSIPP1 atmospheric model. Clim. Dyn. 2005, 25, 517-535. [CrossRef]

53. Cook, K.H.; Vizy, E.K. Coupled model simulations of the West African monsoon system: Twentieth and twenty-first century simulations. J. Clim. 2006, 19, 3681-3703. [CrossRef]

54. Rodríguez-Fonseca, B.; Polo, I.; García-Serrano, J.; Losada, T.; Mohino, E.; Mechoso, C.R.; Kucharski, F. Are Atlantic Niños enhancing Pacific ENSO events in recent decades? Geophys. Res. Lett. 2009, 36. [CrossRef]

55. Landsea, C.W.; Pielke, R.A., Jr.; Mestas-Nunez, A.M.; Knaff, J.A. Atlantic basin hurricanes: Indices of climatic changes. Clim. Chang. 1999, 42, 89-129. [CrossRef]

56. Emanuel, K.A. Tropical Cyclones. Annu. Rev. Earth Planet. Sci. 2003, 31, 75-104. [CrossRef]

57. Blake, E.S.; Rappaport, E.N.; Landsea, C.W. The Deadliest, Costliest, and Most Intense United States Tropical Cyclones from 1851 to 2006 (and Other Frequently Requested Hurricane Facts); NOAA Technical Memorandum NWS TPC-5; National Hurricane Center: Miami, FL, USA, 2007.

58. Gray, W.M. Global view of the origins of tropical disturbances and storms. Mon. Weather Rev. 1968, 96, 669-700. [CrossRef]

59. Landsea, C.W. A climatology of intense (or major) Atlantic hurricanes. Mon. Weather Rev. 1993, 121, $1703-1713$. [CrossRef]

60. Goldenberg, S.B.; Shapiro, L.J. Physical mechanisms for the association of El Niño and West African rainfall with Atlantic major hurricane activity. J. Clim. 1996, 9, 1169-1187. [CrossRef]

61. Saunders, M.A.; Harris, A.R. Statistical evidence links exceptional 1995 Atlantic hurricane season to record sea warming. Geophys. Res. Lett. 1997, 24, 1255-1258. [CrossRef]

62. Gray, W.M. Atlantic seasonal hurricane frequency, Part I: El Niño and $30 \mathrm{mb}$ quasi-biennial oscillation influences. Mon. Weather Rev. 1984, 115, 1649-1668. [CrossRef]

63. Aiyyer, A.; Thorncroft, C. Climatology of vertical shear over the tropical Atlantic. J. Clim. 2006, 19, $2969-2983$. [CrossRef]

64. Bove, M.C.; Elsner, J.B.; Landsea, C.W.; Niu, X.; O’Brien, J.J. Effect of El Niño on U.S. landfalling hurricanes, revisited. Bull. Am. Meteorol. Soc. 1998, 79, 2477-2482. [CrossRef]

65. Elsner, J.B.; Bossak, B.H.; Nui, X.F. Secular changes to the ENSO-U.S. hurricane relationship. Geophys. Res. Lett. 2001, 28, 4123-4126. [CrossRef]

66. Smith, S.R.; Brolley, J.; Tartaglione, C.A. ENSO's impact on regional U.S. hurricane activity. J. Clim. 2007, 20, 1404-1414. [CrossRef]

67. Shapiro, L.J. Hurricane climatic fluctuations. Part II: Relation to large-scale circulation. Mon. Weather Rev. 1982, 110, 1014-1023. [CrossRef]

68. Gray, W.M. Atlantic seasonal hurricane frequency. Part II: Forecasting its variability. Mon. Weather Rev. 1984, 112, 1669-1683. [CrossRef]

69. Tartaglione, C.A.; Smith, S.R.; O'Brien, J.J. ENSO Impact on Hurricane Landfall Probabilities for the Caribbean. J. Clim. 2003, 16, 2925-2931. [CrossRef]

70. Gray, W.M.; Sheaffer, J.D.; Landsea, C.W. Climate Trends Associated with Multidecadal Variability of Atlantic Hurricane Activity. Hurricanes, Climate and Socioeconomic Impacts; Diaz, H.F., Pulwarty, R.S., Eds.; Springer: Berlin, Germany, 1997; pp. 15-53.

71. Goldenberg, S.B.; Landsea, C.W.; Mestas-Nunez, A.M.; Gray, W.M. The recent increase in Atlantic hurricane activity: Causes and implications. Science 2001, 293, 474-479. [CrossRef] [PubMed]

72. Bell, G.D.; Chelliah, M. Leading tropical modes associated with interannual and multidecadal fluctuations in North Atlantic hurricane activity. J. Clim. 2006, 19, 590-612. [CrossRef]

73. Nogueira, R.C.; Keim, B.D.; Brown, D.P.; Robbins, K.D. Variability of rainfall from tropical cyclones in the eastern USA and its association to the AMO and ENSO. Theor. Appl. Climatol. 2013, 112, 273-283. [CrossRef] 
74. Vecchi, G.A.; Soden, B.J. Global warming and the weakening of the tropical circulation. J. Clim. 2007, 20, 4316-4340. [CrossRef]

75. Emanuel, K.A.; Sundararajan, R.; Williams, J. Hurricanes and global warming: Results from downscaling IPCC AR4 simulations. Bull. Am. Meteorol. Soc. 2008, 89, 347-367. [CrossRef]

76. Bender, M.A.; Knutson, T.R.; Tuleya, R.E.; Sirutis, J.J.; Vecchi, G.A.; Garner, S.T.; Held, I.M. Modeled Impact of Anthropogenic Warming on the Frequency of Intense Atlantic Hurricanes. Science 2010, 327, 454-458. [CrossRef] [PubMed]

77. Knight, J.R.; Allan, R.J.; Folland, C.K.; Vellinga, M.; Mann, M.E. A signature of persistent natural thermohaline circulation cycles in observed climate. Geophys. Res. Lett. 2005, 32. [CrossRef]

78. Randel, W.J.; Wu, F. Biases in stratospheric and tropospheric temperature trends derived from historical radiosonde data. J. Clim. 2006, 19, 2094-2104. [CrossRef]

79. Landsea, C.W. Hurricanes and global warming: Arising from Emanuel 2005a. Nature 2005, 438, E11-E13. [CrossRef] [PubMed]

80. Chan, J.C.L. Comment on "Changes in tropical cyclone number, duration, and intensity in a warming environment". Science 2006, 311. [CrossRef] [PubMed]

81. Giannini, A.; Cane, M.; Kushnir, Y. Interdecadal Changes in the ENSO Teleconnection to the Caribbean Region and the North Atlantic Oscillation. J. Clim. 2001, 14, 2867-2879. [CrossRef]

82. Ruiz-Barradas, A.; Carton, J.A.; Nigam, S. Role of the Atmosphere in Climate Variability of the Tropical Atlantic. J. Clim. 2003, 16, 2052-2065. [CrossRef]

83. Wang, C.; Picaut, J. Understanding ENSO physics-A review. Earth Clim. 2004. [CrossRef]

84. Mathieu, P.-P.; Sutton, R.T.; Dong, B.; Collins, M. Predictability of Winter Climate over the North Atlantic European Region during ENSO Events. J. Clim. 2004, 17, 1953-1974. [CrossRef]

85. Pozo-Vázquez, D.; Esteban-Parra, M.J.; Rodrigo, F.S.; Castro-Díez, Y. A study of NAO variability and its possible non-linear influences on European surface temperature. Clim. Dyn. 2001, 17, 701-715. [CrossRef]

86. Gouirand, I.; Moron, V. Variability of the impact of El Niño-Southern Oscillation on sea-level pressure anomalies over the North Atlantic in January to March(1874-1996). Int. J. Climatol. 2003, 23, 1549-1566. [CrossRef]

87. Sutton, R.T.; Hodson, D.L.R. Influence of the Ocean on North Atlantic Climate Variability 1871-1999. J. Clim. 2003, 16, 3296-3313. [CrossRef]

88. Sung, M.-K.; Kim, B.-M.; An, S.-I. Altered atmospheric responses to eastern Pacific and central Pacific El Niños over the North Atlantic region due to stratospheric interference. Clim. Dyn. 2014, 42, 159-170. [CrossRef]

89. Ham, Y.-G.; Sung, M.-K.; An, S.-I.; Schubert, S.D.; Kug, J.-S. Role of tropical atlantic SST variability as a modulator of El Niño teleconnections. Asia Pac. J. Atmos. Sci. 2014, 50, 247-261. [CrossRef]

90. Honda, M.; Nakamura, H.; Ukita, J.; Kousaka, I.; Takeuchi, K. Interannual Seesaw between the Aleutian and Icelandic Lows. Part I: Seasonal Dependence and Life Cycle. J. Clim. 2001, 14, 1029-1042. [CrossRef]

91. Seager, R.; Naik, N.; Ting, M.; Cane, M.A.; Harnik, N.; Kushnir, Y. Adjustment of the atmospheric circulation to tropical Pacific SST anomalies: Variability of transient eddy propagation in the Pacific-North America sector. Q. J. R. Meteorol. Soc. 2010, 136, 277-296. [CrossRef]

92. Li, Y.; Lau, N.C. Impact of ENSO on the atmospheric variability over the North Atlantic in late winter-Role of transient eddies. J. Clim. 2012, 25, 320-342. [CrossRef]

93. Li, Y.; Lau, N.C. Contributions of downstream eddy development to the teleconnection between ENSO and the atmospheric circulation over the North Atlantic. J. Clim. 2012, 25, 4993-5010. [CrossRef]

94. Drouard, M.; Rivière, G.; Arbogast, P. The North Atlantic Oscillation response to large-scale atmospheric anomalies in the northeastern Pacific. J. Atmos. Sci. 2013, 70, 2854-2874. [CrossRef]

95. Drouard, M.; Rivière, G.; Arbogast, P. The Link between the North Pacific Climate Variability and the North Atlantic Oscillation via Downstream Propagation of Synoptic Waves. J. Clim. 2015, 28, 3957-3976. [CrossRef]

96. Mo, K.C.; Livezey, R.E. Tropical-Extratropical Geopotential Height Teleconnections during the Northern Hemisphere Winter. Mon. Weather Rev. 1986, 114, 2488-2515. [CrossRef]

97. Barnston, A.G.; Livezey, R.E. Classification, seasonality and persistence of low-frequency atmospheric circulation patterns. Mon. Weather Rev. 1987, 115, 1083-1126. [CrossRef] 
98. Livezey, R.E.; Mo, K.C. Tropical-extratropical teleconnections during the Northern Hemisphere winter. Part II: Relationships between monthly mean Northern Hemisphere circulation patterns and proxies for tropical convection. Mon. Weather Rev. 1987, 115, 3115-3132. [CrossRef]

99. Yu, B.; Zhang, X.; Lin, H.; Yu, J.Y. Comparison of Wintertime North American Climate Impacts Associated with Multiple ENSO Indices. Atmos. Ocean. 2015, 53, 426-445. [CrossRef]

100. Bladé, I.; Newman, M.; Alexander, M.A.; Scott, J.D. The late fall extratropical response to ENSO: Sensitivity to coupling and convection in the tropical West Pacific. J. Clim. 2008, 21, 6101-6118. [CrossRef]

101. Karoly, D.J.; Plumb, R.A.; Ting, M. Examples of the Horizontal Propagation of Quasi-stationary Waves. J. Atmos. Sci. 1989, 46, 2802-2811. [CrossRef]

102. Greatbatch, R.J.; Lu, J.; Peterson, K.A. Nonstationary impact of ENSO on Euro-Atlantic winter climate. Geophys. Res. Lett. 2004, 31. [CrossRef]

103. Kang, I.-S.; No, H.-H.; Kucharski, F. ENSO Amplitude Modulation Associated with the Mean SST Changes in the Tropical Central Pacific Induced by Atlantic Multidecadal Oscillation. J. Clim. 2014, 27, 7911-7920. [CrossRef]

104. Fedorov, A.V.; Philander, S.G. Is El Niño changing? Science 2000, 288, 1997-2002. [CrossRef] [PubMed]

105. Wang, B.; An, S.I. A mechanism for decadal changes of ENSO behavior: roles of background wind changes. Clim. Dyn. 2002, 18, 475-486.

106. Larkin, N.K.; Harrison, D.E. Global seasonal temperature and precipitation anomalies during El Niño autumn and winter. Geophys. Res. Lett. 2005, 32. [CrossRef]

107. An, S.-I.; Ye, Z.; Hsieh, W.W. Changes in the leading ENSO modes associated with the late 1970s climate shift: Role of surface zonal current. Geophys. Res. Lett. 2006, 33. [CrossRef]

108. Ashok, K.; Behera, S.K.; Rao, S.A.; Weng, H.; Yamagata, T. El Niño Modoki and its possible teleconnections. J. Geophys. Res. 2007, 112. [CrossRef]

109. Yeh, S.W.; Kug, J.S.; Dewitte, B.; Kwon, M.H.; Kirtman, B.P.; Jin, F.F. El Niño in a changing climate. Nature 2009, 461, 511-514. [CrossRef] [PubMed]

110. Choi, J.; An, S.I.; Kug, J.S.; Yeh, S.W. The role of mean state on changes in El Niño's flavor. Clim. Dyn. 2011, 37, 1205-1215. [CrossRef]

111. Graf, H.-F.; Zanchettin, D. Central Pacific El Niño, the "subtropical bridge", and Eurasian climate. J. Geophys. Res. 2012, 117. [CrossRef]

112. Sanders, F.; Gyakum, J.R. Synoptic-dynamic climatology of the "bomb". Mon. Weather Rev. 1980, 108, $1589-1606$. [CrossRef]

113. Folland, C.K.; Knight, J.; Linderholm, H.W.; Fereday, D.; Ineson, S.; Hurrel, J.W. The summer North Atlantic Oscillation: Past, present and future. J. Clim. 2009, 22, 1082-1103. [CrossRef]

114. Wu, Z.; Lin, H. Interdecadal variability of the ENSO-North Atlantic Oscillation connection in boreal summer. Q. J. R. Meteorol. Soc. 2012, 138, 1668-1675. [CrossRef]

115. Wang, H.; Wang, B.; Huang, F.; Ding, Q.; Lee, J.Y. Interdecadal change of the boreal summer circumglobal teleconnection (1858-2010). Geophys. Res. Lett. 2012, 39. [CrossRef]

116. Saeed, S.; van Lipzig, N.; Müller, W.A.; Saeed, F.; Zanchettin, D. Influence of the circumglobal wave-train on European summer precipitation. Clim. Dyn. 2014, 43, 503-515. [CrossRef]

117. Capa-Morocho, M.; Rodríguez-Fonseca, B.; Ruiz-Ramos, M. Crop yield as a bioclimatic index of El Niño impact in Europe: Crop forecast implications. Agric. For. Meteorol. 2014, 198, 42-52. [CrossRef]

118. Rozas, V.; Camarero, J.J.; Sangüesa-Barreda, G.; Souto, M.; García-Gonzalez, I. Summer drought and ENSO-related cloudiness distinctly drive Fagus sylvatica growth near the species rear-edge in northern Spain. Agric. For. Meteorol. 2015, 201, 153-164. [CrossRef]

119. Garfinkel, C.I.; Hartmann, D.L. Different ENSO teleconnections and their effects on the stratospheric polar vortex. J. Geophys. Res. 2008, 113. [CrossRef]

120. Garfinkel, C.I.; Hartmann, D.L.; Sassi, F. Tropospheric precursors of anomalous Northern Hemisphere stratospheric polar vortices. J. Clim. 2010, 23, 3282-3299. [CrossRef]

121. Taguchi, M.; Hartmann, D.L. Increased occurrence of stratospheric sudden warmings during El Niño as simulated by WACCM. J. Clim. 2006, 19, 324-332. [CrossRef]

122. Labitzke, K.; van Loon, H. The Stratosphere: Phenomena, History, and Relevance; Springer: Berlin, Germany, 1999; p. 179. 
123. Butler, A.H.; Polvani, L.M. El Niño, La Niña, and stratospheric sudden warmings: A reevaluation in light of the observational record. Geophys. Res. Lett. 2011, 38. [CrossRef]

124. Garfinkel, C.I.; Butler, A.H.; Waugh, D.W.; Hurwitz, M.M.; Polvani, L.M. Why might stratospheric sudden warmings occur with similar frequency in El Niño and La Niña winters? J. Geophys. Res. 2012, 117. [CrossRef]

125. Brönimann, S.; Luterbacher, J.; Staehelin, J.; Svendby, T.M.; Hansen, G.; Svenoe, T. Extreme climate of the global troposphere and stratosphere in 1940-1942 related to El Niño. Nature 2004, 431, 971-974. [CrossRef] [PubMed]

126. Bell, C.J.; Gray, L.J.; Charlton-Perez, A.J.; Joshi, M.M. Stratospheric communication of El Niño teleconnections to European winter. J. Clim. 2009, 22, 4083-4096. [CrossRef]

127. Cagnazzo, C.; Manzini, E. Impact of the stratosphere on the winter tropospheric teleconnections between ENSO and the North Atlantic and European region. J. Clim. 2009, 22, 1223-1238. [CrossRef]

128. Butler, A.H.; Polvani, L.M.; Deser, C. Separating the stratospheric and the tropospheric pathways of El Niño-Southern Oscillation teleconnections. Environ. Res. Lett. 2014, 9. [CrossRef]

129. Zubiaurre, I.; Calvo, N. The El Niño-Southern Oscillation (ENSO) Modoki signal in the stratosphere. J. Geophys. Res. 2012, 117. [CrossRef]

130. Hurwitz, M.M.; Calvo, N.; Garfinkel, C.I.; Butler, A.H.; Ineson, S.; Cagnazzo, C.; Manzini, E.; Peña-Ortiz, C. Extra-tropical atmospheric response to ENSO in the CMIP5 models. Clim. Dyn. 2014. [CrossRef]

131. Iza, M.; Calvo, N. Role of stratospheric sudden warmings on the response to Central Pacific El Niño. Geophys. Res. Lett. 2015, 42, 2482-2489. [CrossRef]

132. Hurrell, J.W.; Kushnir, Y.; Ottersen, G.; Visbeck, M. An Overview of the North Atlantic Oscillation, Climatic Significance and Environmental Impact; Hurrell, J.W., Kushnir, Y., Ottersen, G., Visbeck, M., Eds.; American Geophysical Union: Washington, DC, USA, 2003.

133. Ineson, S.; Scaife, A.A. The role of the stratosphere in the European climate response to El Niño. Nat. Geosci. 2009, 2, 32-36. [CrossRef]

134. Mariotti, A.; Zeng, N.; Lau, K.M. Euro-Mediterranean rainfall and ENSO-A seasonally varying relationship. Geophys. Res. Lett. 2002, 29. [CrossRef]

135. Knippertz, P.; Ulbrich, U.; Marques, F.; Corte-Real, J. Decadal changes in the link between El Niño and springtime North Atlantic Oscillation and European-North African rainfall. Int. J. Climatol. 2003, 23, 1293-1311. [CrossRef]

136. Zanchettin, D.; Franks, S.W.; Traverso, P.; Tomasino, M. On ENSO impacts on European wintertime rainfalls and their modulation by the NAO and the Pacific multi-decadal variability described through the PDO index. Int. J. Climatol. 2008, 28, 995-1006. [CrossRef]

137. Ting, M.; Hoerling, M.P.; Xu, T.; Kumar, A. Northern Hemisphere teleconnection patterns during extreme phases of the zonal-mean circulation. J. Clim. 1996, 9, 2614-2633. [CrossRef]

138. Martín-Rey, M.; Rodríguez-Fonseca, B.; Polo, I. Atlantic opportunities for ENSO prediction. Geophys. Res. Lett. 2015, 42, 6802-6810. [CrossRef]

139. Losada, T.; Rodriguez-Fonseca, B.; Kucharski, F. Tropical influence on the summer Mediterranean climate. Atmos. Sci. Lett. 2012, 13, 36-42. [CrossRef]

(C) 2016 by the authors; licensee MDPI, Basel, Switzerland. This article is an open access article distributed under the terms and conditions of the Creative Commons Attribution (CC-BY) license (http://creativecommons.org/licenses/by/4.0/). 